\section{Ks. Mirosław Mejzner SAC}

Uniwersytet Kardynała Stefana Wyszyńskiego w Warszawie m.mejzner@uksw.edu.pl

DOI: http://dx.doi.org/10.12775/BPTh.2017.005

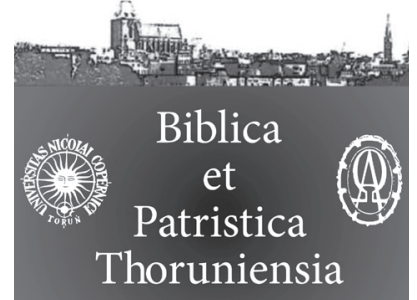

10 (2017) 1: 101-118

ISSN (print) 1689-5150

ISSN (online) 2450-7059

\title{
Unde malum? w „De autexusio" Metodego z Olimpu
}

\section{Unde malum? in Methodius of Olympus' "De autexusio"}

Streszczenie. Zasadniczym celem dialogu „O wolnej woli” (De autexusio) Metodego z Olimpu ( $† 311)$ jest próba znalezienia odpowiedzi na pytanie o pochodzenie zła. Autor przeprowadził w nim gruntowną krytykę dualistycznych twierdzeń średniego platonizmu na temat powstania materii i natury zła, lansując pogląd o stworzeniu z nicości. Dzięki kategorii wolnej woli człowieka zdefiniował zło jako akt podmiotu działającego. Pierwszorzędnym celem niniejszego studium jest analiza argumentacji zawartej w De autexusio, ze szczególnym uwzględnieniem ideowych pozycji prezentowanych przez poszczególnych rozmówców.

\begin{abstract}
The fundamental aim in Methodius of Olympus' (†311) “On Free Will” (De autexusio), is an attempt to find an explanation for a question of the origin of evil. In it, while promoting the opinion of creation from non-existence, the author conducted a thorough critique of the dualistic arguments of Middle Platonism on the topic of the origin of matter and the nature of evil. Because of the concept of man's free will, he defined evil as an action of the relevant entity. The main objective of this study is an analysis of the reasoning within De autexusio, with particular consideration of the ideological positions presented by the respective interlocutors.
\end{abstract}

Słowa kluczowe: Metody z Olimpu; wolna wola; zło; materia; substancja; jakości; stworzenie z nicości.

Keywords: Methodius of Olympus; free will; evil; matter; substance; qualities; creation ex nihilo.

Tednym z uniwersalnych i najtrudniejszych pytań ludzkości jest to o pochodzenie zła i cierpienia. Znajdowało ono różne wyjaśnienia w mitologiach, wierzeniach, filozofiach. W Biblii zagadnienie początków zła pojawia się już w pierwszych rozdziałach Księgi Rodzaju (np. grzech Adama i Ewy [Rdz 3]; zabójstwo Abla przez Kaina [Rdz 4,1-15]; niegodziwość ludzi zgładzona potopem [Rdz 6,1-7]; wieża Babel [Rdz 11, 1-9] etc.), przewija przez wszystkie księgi aż po ostateczną wojnę Boga z diabłem w Gog i Magog (Ap 20,8-10). 
Niewinne cierpienie sprawiedliwego jest zasadniczym tematem Księgi Hioba, który - podobnie jak cierpiący Sługa Pański (Iz 53,1-12), jest typem Chrystusa z jego rozdzierającym krzykiem na krzyżu: „Boże mój, Boże mój, czemuś mnie opuścił?" (Mt 27,46) ${ }^{1}$.

Pierwsi autorzy chrześcijańscy poszukiwali odpowiedzi na pytanie nie tylko o pierwotne przyczyny zła, lecz także starali się wyjaśnić powody, dlaczego ono wciąż trwa. Broniąc poglądu o jedyności Stwórcy i ontycznej dobroci stworzenia byli zmuszeni do konfrontacji ze zwolennikami dualizmu. Ci ostatni bowiem odpowiedzialnością za wszelkie zło obciążali materię, a zbawienia upatrywali w całkowitym wyzwoleniu z ciała. Dialog Metodego z Olimpu († 311) „O wolnej woli” (De autexusio), wciąż czekający na przekład w języku polskim, jest jednym $\mathrm{z}$ bardziej znaczących dzieł tego ważnego, choć nieco zapomnianego autora, żyjącego na przełomie III i IV $\mathrm{w}^{2}$. Autor podjął $\mathrm{w}$ nim polemikę z dualistycznymi poglądami na temat powstania materii i pochodzenia zła, wprowadzając kategorię wolnej woli człowieka jako zasadniczej rzeczywistości, pozwalającej wyjaśnić wspomniane dylematy.

Zasadniczym celem niniejszego studium jest analiza argumentacji zawartej w De autexusio, tak by zaprezentować stanowiska ideowe dyskutujących rozmówców, wyartykułować ich założenia metafizyczne i dokonać syntezy ich poglądów na temat przyczyn zła w świecie. Ze względu na znikomą znajomość tego dzieła w polskiej literaturze zostaną też przedstawione pewne zagadnienia wstępne, tj. kwestia jego autorstwa, datacja, historyczna recepcja i nowożytne edycje De autexusio.

\section{Starożytna enigma autorstwa}

Wątpliwości dotyczące autorstwa dzieła rozpoczęły się już w starożytności, zaledwie kilkanaście lat po śmierci Metodego. Za głównego sprawcę zamieszania należy uznać Euzebiusza z Cezarei (†340), który ze względu na krytyczny stosunek biskupa Olimpu do niektórych poglądów Orygensa, wyraźnie pomniej-

1 Teologiczna interpretacja tego wersetu i odkupieńczej ofiary Chrystusa, por. M. Mejzner, Wędrówki ku sacrum, s. 50-57.

2 Wiadomości o Metodym są bardzo skąpe i oparte na niepewnych źródłach. Informacje przekazane przez Hieronima (De viris illustribus 83) są pełne sprzeczności. Jego dzieła świadczą o wysokiej kulturze literackiej i filozoficznej autora, zanurzonego w debaty teologiczne swojej epoki. Najprawdopodobniej był biskupem Olimpu i zginął śmiercią męczeńską podczas prześladowań Dioklecjana ok. 311 roku. Szerzej na temat biografii i twórczości Metodego, por. M. Mejzner, Zapomniany nauczyciel wiary; S. B. Zorzi, Metodio d'Olimpo, un autore minore? 
szał znaczenie tego pierwszego. W swojej Historii kościelnej nawet o nim nie wspomniał, choć z pewnością dobrze znał jego dzieła, czego dowodzi świadectwo Hieronima ${ }^{3}$. Otóż tenże Euzebiusz w dziele Praeparatio evangelica zamieścił długi passus krytykujący teorie dualistyczne, wskazując jako swe źródło dzieło „O materii” niejakiego Maksyma ${ }^{4}$. Pomijając fakt, że skądinąd nic nie wiadomo na temat takiego autora ${ }^{5}$, jest o wiele bardziej znaczące, że passus ten odpowiada fragmentowi De autexusio V,1-XII,8. Sytuacja jest jednak o wiele bardziej skomplikowana, gdyż passus ten znalazł się również w Philocalia XXIV. Bazyli z Cezarei i Grzegorz z Nazjanzu, przytoczywszy go zaświadczyli, że tekst z siódmej księgi Praeparatio evangelica odpowiada części znanego im dialogu De recta in Deum fide, autorstwa niejakiego Adamancjusza, którego utożsamili z Orygenesem. Tę ostatnią wersję podzielał też Rufin, który przetłumaczył dzieło na łacinę.

\section{Recepcja i edycja De autexusio}

Występowanie trzech postaci (Maksyma, Orygenesa i Metodego) jako potencjalnych autorów interesującego nas passusu, wzbudziło zainteresowanie nowożytnych badaczy i doprowadziło do postawienia wielu hipotez. Barnes próbował wykazać, że Maksym był postacią historyczną i autorem dzieła zatytułowanego „O materii i początku zła”, które utożsamiał z dialogiem De recta in Deum fide. Jego zdaniem to właśnie ono było źródłem zarówno dla Euzebiusza, jak i Metodego ${ }^{6}$.

Jan Meursius już w XVII wieku otworzył drogę ku innemu rozwiązaniu, które wzmocnione w ciągu wieków kolejnymi odkryciami i solidnymi argumentami, jest dziś powszechnie uznawane. W manuskrypcie Laurentianus 9,23 z X wieku, przechowywanym w bibliotece we Florencji, odnalazł on bowiem długi passus (dokładnie rozdziały I - VII,5) dialogu Metodego „O wolnej woli”. Takie autorstwo dzieła jest też poświadczane przez autora Sacra Parallela 431432, Focjusza (Biblioteka 236), Enzika z Kołb, a zwłaszcza przez manuskrypty staro-cerkiewno-słowiańskie, w których zachowało się wiele, skądinąd nieznanych dzieł Metodego. Ostateczne rozwiązanie dylematu autorstwa przyniosły badania dziewiętnastowieczne. Dokładne porównanie paralelnych passusów

3 Hieronymus, Apologia adversus libros Rufini I, 11, SCh 303, s. 30.

4 Praeparatio evangelica VII, 22.

5 Szerzej: R. Franchi, Eusebio di Cesarea, Hist. Eccl. 5.27 e Praep. Ev. 7.21.5; I. Ramelli, Maximus on Evil; S. B. Zorzi, Introduzione: Metodio di Olimpo, s. 6-7.

6 T. D. Barnes, Methodius, s. 54-55. 
De autexusio, Praeparatio evangelica i Philocalia, wraz z pogłębionymi studiami nad dziełami Metodego (M.J. Routh7, A. Jahn ${ }^{8}$, T. von Zahn', J.A. Robinson ${ }^{10}$ ) doprowadziły do wykazania źródłowego charakteru tego pierwszego dzieła ${ }^{11}$. Dwaj ostatni badacze wysunęli ponadto hipotezę, próbującą wyjaśnić pomyłkę Euzebiusza. Ich zdaniem Maksym był jednym z bohaterów De autexusio, a jego imię mogło pojawić się w tytule, wprowadzając w błąd autora Praeparatio evangelica, który uznał tę postać za twórcę całego dzieła ${ }^{12}$. Hipoteza ta, jak słusznie ocenił Vaillant, jest jednak bardziej błyskotliwa niż oparta na solidnym fundamencie. Według niego dialog Metodego krążył prawdopodobnie w wersji anonimowej, a jego treść - odpowiadająca dyskusjom z wcześniejszej o sto lat epoki apologetów - wprowadziła w błąd Euzebiusza, który nie domyślił się, kto był rzeczywistym autorem ${ }^{13}$. Rozwiązanie tego problemu nie jest jednak przedmiotem niniejszego studium.

Zawiła historia recepcji dzieł Metodego, ukazana na przykładzie De aute$x_{u s i o}{ }^{14}$, znalazła swój wyraz w trudnościach dotyczących wydania edycji krytycznej. Złożona tradycja manuskryptowa, skomplikowana dodatkowo przez konieczność korzystania ze starożytnych przekładów ormiańskich i staro-cerkiewno-słowiańskich, sprawiła, że pierwszego i jedynego dotąd wydania pism Metodego dokonał w 1917 roku G.N. Bonwetsch ${ }^{15}$, który passusy znane jedynie z manuskryptów słowiańskich przetłumaczył na język niemiecki. Kilkanaście lat później, A. Vaillant dokonał edycji De autexusio wraz z tekstem staro-cerkiewno-słowiańskim, podejmując jednocześnie próbę retranslacji tych

7 Reliquiae Sacrae.

8 S. Methodii opera.

9 Die Dialoge.

10 The Philocalia of Origen, s. 40-41.

11 Szerzej na ten temat: A. Vaillant, Introduction, s. 637-639, 648-653; R. Franchi, Introduzione, s. 44-46, 138-140; Appendice IX, s. 407-412.

12 Dzieła Metodego często posiadają w manuskryptach podwójny tytuł, np. Aglaofone lub o zmartwychwstaniu; Xenon lub o stworzeniu; Systeliusz lub o trądzie. W podobny sposób interesujące nas dzieło było być może niekiedy zatytułowane Maksym lub o wolnej woli.

13 A. Vaillant, Introduction, s. 639-640, 648-653.

14 Manuskrypty słowiańskie, na podstawie których Bonwetsch przygotował wydanie krytyczne Corpus Methodianum (GCS 27), zawierają wszystkie znane dziś dzieła biskupa Olimpu. Warto podkreślić, że w dwóch manuskryptach z XIII-XIV wieku (BAR 72, s. $52^{\mathrm{r}}-73^{\mathrm{v}}$ i BAR 310 , s. $\left.121^{\mathrm{r}}-157^{\mathrm{v}}\right)$, przechowywanych w Akademii Nauk w Bukareszcie, zawarty jest tylko jeden dialog Metodego: De autexusio. To jedyny taki przypadek, który świadczy prawdopodobnie o dużym znaczeniu tego dzieła w środowisku kopistów.

15 Methodius: Werke, GCS 27, Leipzig 1917. 
passusów na grekę ${ }^{16}$ oraz oferując przekład francuski. Na tych dwóch edycjach oparła się R. Franchi ${ }^{17}$, która przed dwoma laty wydała spójny tekst dzieła wraz $\mathrm{z}$ tłumaczeniem włoskim i obszernym komentarzem.

\section{Datacja dzieła}

Współcześni badacze pism Metodego nie są zgodni na temat daty powstania dialogu „O wolnej woli”. Badania natury lingwistycznej doprowadziły Buchheita do wniosku, że jest on późniejszy od Symposium („Uczta”), a wcześniejszy od De resurrectione („O zmartwychwstaniu”) ${ }^{18}$. Taką kolejność przyjmują Vaillant ${ }^{19}$ i Moreschini ${ }^{20}$. Przeciwnego zdania jest z kolei Patterson, który twierdzi, że dialog De autexusio powstał bardzo wcześnie, stanowiąc niejako przygotowanie do treści wyrażonych w sposób o wiele bardziej kompleksowy i precyzyjny w późniejszych dziełach ${ }^{21}$. Wczesną datację dzieła przyjmuje też Franchi, wskazując nawet okolice roku $270^{22}$.

\section{Tematyka dysputy}

Bohaterami dialogu „O wolnej woli” są trzej rozmówcy. Dwaj z nich to zwolennicy teorii dualistycznych, których krytykiem jest przedstawiciel doktryny chrześcijańskiej ${ }^{23}$. Polemika nie ma jednak charakteru kłótni, ale zgodnie z zasadami starożytnego gatunku literackiego, stanowi metodę poszukiwania prawdy, której poznanie jest nadrzędnym celem wszystkich ${ }^{24}$. Decyduje nie siła czy podstęp, ale wartość argumentów. Wzorując się na Sokratesie, Metody przez usta ortodoksa za pomocą serii pytań doprowadza swoich rozmówców do zauważenia błędów w swych dotychczasowych przekonaniach i uznania

\footnotetext{
16 Le "De autexusio", PO 22/5.

17 Metodio: Il libero arbitrio.

18 V. Buccheit, Studien, s. 172.

19 A. Vaillant, Introduction, s. 652.

20 C. Moreschini, Storia, s. 176-179.

21 L.G. Patterson, Methodius of Olympus, s. 31.

22 R. Franchi, Introduzione, s. 109-110.

23 Dla potrzeb naszego studium postaci heterodoksyjne zostały nazwane „Dualista 1" (D1) i „Dualista 2” (D2). Poglądy ortodoksyjne wyraża sam Metody (M).

24 Szerzej na temat dialogu jako gatunku literackiego: B.R. Voss, Der Dialog in der frühchristlicher Literatur.
} 
nieprawidłowości pierwotnych założeń. Nie oznacza to jednak, że przyjęli oni ortodoksyjne poglądy. Taki krok pozostaje sprawą przyszłości, co najprawdopodobniej stanowi konwencję przyjętej metody dialogicznej ${ }^{25}$.

Problematyka dzieła nie ogranicza się do tytułowego zagadnienia. Zasadniczym dylematem jest fakt istnienia zła w świecie. Próby jego wyjaśnienia są owocem poszukiwania odpowiedzi na odwieczne pytania o świat duchowy i materialny, zwłaszcza o sposób i przyczyny jego powstania, oraz o pochodzenie i naturę zła. W tym kontekście poruszane są kwestie z pogranicza metafizyki i teodycei oraz te antropologiczne, ogniskujące się w fenomenie wolnej woli człowieka.

W większości dostępnych dziś edycji i tłumaczeń, dialog podzielony jest na 21 rozdziałów ${ }^{26}$. Zawarta w nich argumentacja nie rozwija się w sposób liniowy. Forma dialogu sprawia, że poszczególne tematy są dyskutowane, potem zawieszane, a niekiedy podejmowane od nowa, choć już na głębszym poziomie. Niekiedy dyskusja jest żywa i dynamiczna, innym razem przechodzi w wykład doktrynalny, przyjmując formę traktatu. Duża część dzieła przypomina popularną w szkołach cyników i stoików literacką diatrybę, w której mówca, uprzedzając możliwe obiekcje hipotetycznych adwersarzy, odpowiada na własne pytania. Nie jest zatem łatwo ustalić jakąś przejrzystą strukturę dzieła. Bardzo ogólnikowo dynamikę argumentacji można przedstawić w sposób zaprezentowany w poniższej tabeli ${ }^{27}$.

25 Jedną z charakterystyk dialogów Metodego jest pozostawienie pewnej różnorodności poglądów i swoistej polifonii, wyrażającej subtelne pozycje ideowe rozmówców, por. A. Bril, Plato and the Sympotic Form; E. Prinzivalli, Magister Ecclesiae, s. 107-108.

26 G. N. Bonwetsch (ed.), GCS 27, s. 143-206; R. Franchi, s. 162-339. A. Vaillant (PO 22, 5, s. 726-833), zastosował niestety inny, bardziej skomplikowany podział, co utrudnia proces porównawczy tych edycji.

27 Cyfry w nawiasach oznaczają rozdziały i podpunkty De autexusio według podziałów zawartych w edycji R. Franchi. M - Metody, D1 - pierwszy heterodoks, D2 - drugi heterodkos. 


\begin{tabular}{|c|c|c|}
\hline Rozdz. & Mówca & Tematyka $\mathrm{i}$ argumentacja \\
\hline 1 & M & $\begin{array}{l}\text { Prolog: } \\
\text { Przeciwstawienie nauk Bożych, zawartych w Piśmie Świętym, głosom } \\
\text { „syren”, symbolizujących mądrość pogańską, tj. filozofów greckich } \\
\text { i mitologię. }\end{array}$ \\
\hline 2 & D1 & 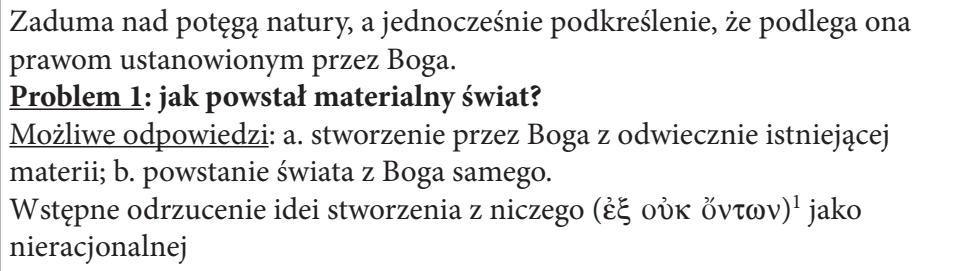 \\
\hline 3 & D1 & $\begin{array}{l}\text { Problem 2: jaka jest relacja Boga i materii? } \\
\text { Fakt istnienia zła na świecie (np. morderstwo, rozkład ciała ludzkiego po } \\
\text { śmierci). } \\
\text { Hipoteza 1: Bóg i materia, której On używa do tworzenia bytów, nadając jej } \\
\text { porządek i formę, istnieją odwiecznie. } \\
\text { Problem 3: jaka jest przyczyna zła? } \\
\text { Hipoteza 2: Bóg jest dobry, zatem zło pochodzi od materii. } \\
\text { Otwartość na dyskusję i racjonalne argumenty. }\end{array}$ \\
\hline $4,1-2$ & M & Streszczenie różnych pozycji filozoficznych odnośnie Problemów 2 i 3. \\
\hline $4,3-5$ & M & $\begin{array}{l}\text { Podkreślenie konieczności poszukiwania prawdy jako nadrzędnego celu } \\
\text { rozważań. }\end{array}$ \\
\hline 5 & M & $\begin{array}{l}\text { Odniesienie do Problemu } 2 \text { (relacja Bóg - materia) } \\
\text { Rozumowanie: gdyby Bóg był całkowicie oddzielony od materii musiałoby } \\
\text { między nimi istnieć jakieś pryncypium pośrednie i ich rozdzielające } \\
(\text { tertium quid). Wniosek: Bóg nie jest oddzielony od materii. }\end{array}$ \\
\hline 6 & M & $\begin{array}{l}\text { Pytanie: Bóg jest w materii czy materia w Bogu? } \\
\text { Rozumowanie: Bóg nie jest w materii. Jednak wyjaśnienie w jaki sposób } \\
\text { materia jest w Bogu stanowi problem. Przyjęcie dualistycznej teorii } \\
\text { o wiecznej materii nie przynosi zadowalającego rozwiązania. } \\
\text { Nawiązanie do Problemu } 3 \text { (o przyczynę zła). }\end{array}$ \\
\hline 7 & M & 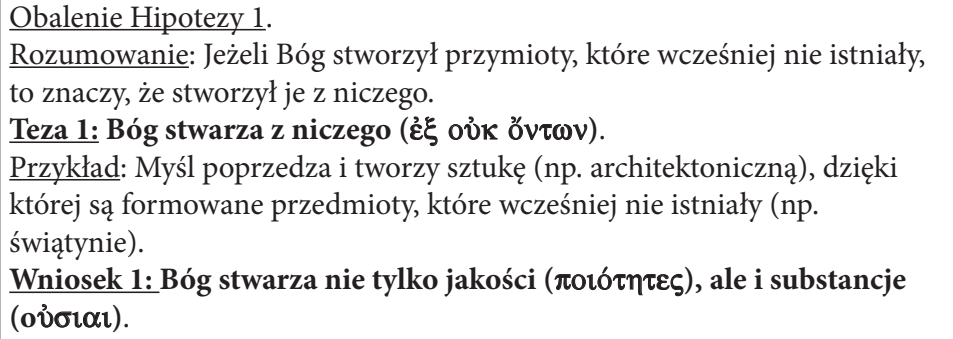 \\
\hline
\end{tabular}




\begin{tabular}{|c|c|c|}
\hline 8,1 & M & $\begin{array}{l}\text { Powrót do Problemu } 3 \\
\text { Pytanie: czy zło jest substancją czy jej przymiotem? }\end{array}$ \\
\hline 8,1 & D1 & Hipoteza 4: zło jest przymiotem substancji \\
\hline 8,2 & M & $\begin{array}{l}\text { Obalenie Hipotezy 4: } \\
\text { Argumentacja: Gdyby materia byłaby odwieczna, a Bóg dałby jej tylko } \\
\text { przymioty, to Bóg byłby autorem zła. }\end{array}$ \\
\hline 8,3 & D1 & $\begin{array}{l}\text { Potwierdzenie gotowości do dyskusji i przyjęcia przekonujących } \\
\text { argumentów }\end{array}$ \\
\hline 8,4 & D1 & $\begin{array}{l}\text { Hipoteza 5: zło jest substancją (materialną). } \\
\text { Argumentacja: zło nie istnieje poza substancjami }\end{array}$ \\
\hline $8,4-9$ & $\mathrm{M}-\mathrm{D} 1$ & $\begin{array}{l}\text { Obalenie Hipotezy 5: } \\
\text { Teza M1: zło jest aktem kogoś kto działa. } \\
\text { Argumentacja: Substancja (cielesna), istnieje niezależnie od pojedynczych } \\
\text { bytów. Zło zaś jest aktem. Akt potrzebuje podmiotu działającego do } \\
\text { zaistnienia. A zatem: zło nie jest substancją. }\end{array}$ \\
\hline 8,10 & M & $\begin{array}{l}\text { Przykład. Przesłanka } 1 \text { (hipotetyczna): zło to substancja; Przesłanka 2: } \\
\text { zabójstwo jest złem. Wniosek: zabójstwo jest substancją. } \\
\text { Wniosek jest błędny, gdyż zabójstwo jest skutkiem aktu podmiotu } \\
\text { działającego (mordercy). Zatem zabójstwo nie jest substancją. } \\
\text { Morderca jako człowiek jest substancją, ale zabójstwo, którego dokonuje, } \\
\text { jest jego aktem (działaniem substancji) }\end{array}$ \\
\hline $8,11-15$ & M & $\begin{array}{l}\text { Wnioski: Zło jest działaniem podmiotu. Złe czyny (np. morderstwo, } \\
\text { cudzołóstwo itp.) mają swojego autora. Czyniący zło nie jest zły z powodu } \\
\text { swojej substancji, ale z racji swoich działań. }\end{array}$ \\
\hline $9,1-3$ & D2 & $\begin{array}{l}\text { Potwierdzenie słuszności rozumowania przeciw Hipotezie } 4 \text {. } \\
\text { Argumentacja: Gdyby Bóg był twórcą jakości materii, to byłby autorem zła. } \\
\text { Hipoteza 6: Materia istnieje odwiecznie wraz z jakościami. Zło istnieje } \\
\text { w materii i od niej pochodzi. }\end{array}$ \\
\hline 9,4 & M & Wezwanie do precyzji myślenia i sformułowań. \\
\hline $10,1-2$ & M & $\begin{array}{l}\text { Odrzucenie Hipotezy } 6 \\
\text { Argumentacja: jeśli substancja (materialna) istnieje odwiecznie wraz } \\
\text { z przymiotami, to Bóg niczego nie stworzył, a zatem nie jest Stwórcą. } \\
\text { Pytanie: czego dokonał Bóg w akcie stworzenia? }\end{array}$ \\
\hline $10,3-4$ & D2 & $\begin{array}{l}\text { Hipoteza 7: Substancja materii jest niezmienna i odwieczna, natomiast } \\
\text { zmienne są jej niektóre jakości. } \\
\text { Argumentacja: Bóg zmienia na lepsze (obojętne) jakości materii i w tym } \\
\text { sensie jest nazywany Stworzycielem. }\end{array}$ \\
\hline
\end{tabular}




\begin{tabular}{|c|c|c|}
\hline $10,5-8$ & $\mathrm{M}-\mathrm{D} 2$ & $\begin{array}{l}\text { Przygotowanie do odrzucenia Hipotezy } 7 . \\
\text { Rozumowanie: Jeśli zło jest w jakościach substancji, i jeśli te jakości istnieją } \\
\text { od zawsze, i jeśli Bóg dokonał zmiany (pewnych) jakości, to dokonał ich } \\
\text { przemiany w lepsze. }\end{array}$ \\
\hline 11 & M & $\begin{array}{l}\text { Odrzucenie Hipotezy } 7 . \\
\text { Argumentacja: jeśli Bóg, pomimo przemiany jakości, pozostawia zło to albo } \\
\text { jest odpowiedzialny za jego istnienie (mógł je unicestwić, a tego nie uczynit), } \\
\text { albo nie jest wszechmocny (nie mógł go unicestwić). } \\
\text { Wniosek: Hipoteza } 7 \text { nie wyjaśnia przyczyn zła i jest błędna. }\end{array}$ \\
\hline 12 & $\begin{array}{l}\mathrm{M} \\
\mathrm{M}-\mathrm{D} 2\end{array}$ & $\begin{array}{l}\text { Pytanie: jaka jest natura materii - prosta czy złożona? } \\
\text { Argumentacja ukierunkowana na wykazanie, że materia nie istnieje } \\
\text { wiecznie. Analiza złożoności bytów, prostoty substancji i elementów oraz } \\
\text { istnienia w świecie zwalczających się przeciwieństw. }\end{array}$ \\
\hline 13 & M & $\begin{array}{l}\text { Powrót do Problemu } 3 \text { (przyczyny zła) i przywołanie Tezy M1. } \\
\text { Argumentacja: gatunek nie istnieje niezależnie od jednostek, lecz wyraża } \\
\text { się w nich; podobnie zło (np. zabójstwa, cudzołóstwa) istnieje w tych, } \\
\text { którzy go dokonują. } \\
\text { Wniosek: zło nie istnieje odwiecznie, lecz ma swój początek. }\end{array}$ \\
\hline $14,1-2$ & D1-M & $\begin{array}{l}\text { Wezwanie do jeszcze bardziej precyzyjnej argumentacji i otwartości na } \\
\text { poszukiwanie prawdy. }\end{array}$ \\
\hline $14,3-6$ & $\mathrm{M}-\mathrm{D} 1$ & $\begin{array}{l}\text { Dyskusja na temat czy Bóg jest autorem zła (tzn. złych działań)? } \\
\text { Argumentacja: Boża sprawiedliwość, wyrażająca się w karaniu, nie jest } \\
\text { złem, choć subiektywnie może być uważana za takowe przez ukaranego. }\end{array}$ \\
\hline 15 & M & $\begin{array}{l}\text { Teza M2 (rozwinięcie M1): Nic nie jest złe z natury, ale ze względu na } \\
\text { użycie lub działanie. } \\
\text { Argumentacja: Działanie zgodne z porządkiem jest dobre, a wbrew niemu - } \\
\text { złe. Np. relacja miłości między mężem a żoną ukierunkowana na zrodzenie } \\
\text { potomstwa jest dobra, a relacja cudzołożna - zła; podobnie zabójstwo } \\
\text { niewinnego - złe, ale ukaranie zbrodniarza - uprawnione. Akt adoracji } \\
\text { skierowany ku Bogu jest właściwy, a ten do bożków jest idolatrią. Podobnie } \\
\text { substancja (np. żelaza) może być użyta do dobrego lub złego czynu. }\end{array}$ \\
\hline 16,1 & $\mathrm{D}$ & $\begin{array}{l}\text { Pytanie: Od kogo pochodzi zło w człowieku (od niego samego, Boga czy } \\
\text { jeszcze kogoś innego)? }\end{array}$ \\
\hline $16,2-10$ & M & $\begin{array}{l}\text { Teza M3: wolna wola to największy dar Boga dla człowieka. } \\
\text { Argumentacja: Człowiek został stworzony bez złych pragnień jako istota } \\
\text { rozumna i wolna. Wolna wola to największy dar Boga dla człowieka } \\
\text { w perspektywie otrzymania większych dóbr, tj. niezniszczalności i życia } \\
\text { wiecznego. Dzięki wolnej woli człowiek ma współudział w osiągnięciu } \\
\text { wieczności zgodnie z planem Boga, który ukazuje dobro i zachęca do jego } \\
\text { osiągnięcia. Posłuszeństwo przykazaniu Bożemu jest drogą rozumnego } \\
\text { osiągnięcia wyższego dobra. }\end{array}$ \\
\hline
\end{tabular}




\begin{tabular}{|c|c|c|}
\hline 17 & M & $\begin{array}{l}\text { Rozwinięcie Tezy M3 (w oparciu o Tezę M1 i Tezę M2): } \\
\text { Nie istnieje odwieczne zło. Człowiek sam jest sprawcą swojego } \\
\text { posłuszeństwa lub nieposłuszeństwa wobec Boga. } \\
\text { Wniosek: Zło nie przynależy do ludzkiej natury, ale ma swój początek } \\
\text { w nieposłuszeństwie Bogu. } \\
\text { Teza M4: Człowiek nauczył się nieposłuszeństwa od diabła, który zwiódł } \\
\text { go z powodu zazdrości. } \\
\text { Argumentacja: Powodem zazdrości był wyjątkowy status człowieka, który } \\
\text { jako jedyny został ukształtowany na obraz i podobieństwo Boże². }\end{array}$ \\
\hline 18 & M & $\begin{array}{l}\text { Pytanie: jeśli nikt nie jest zły z natury to skąd się wzięło poznanie zła } \\
\text { u diabła? } \\
\text { Argumentacja (rozwinięcie Tezy M4): } \\
\text { Zło diabła było wynikiem jego zazdrości o człowieka. To zło polegało } \\
\text { na nieposłuszeństwie. Dlatego starał się skłonić człowieka do } \\
\text { nieposłuszeństwa, choć początkowo nie wiedział na czym ma ono polegać } \\
\text { i jakie skutki przyniesie. } \\
\text { Zło jest przeciwieństwem dobra, a polega ono na nieposłuszeństwie } \\
\text { przykazaniu Bożemu. Diabeł wykorzystał przestrogę, którą Bóg skierował } \\
\text { do człowieka, a mianowicie, by ten nie spożywał owocu z drzewa } \\
\text { poznania dobra i zła. Na zasadzie przeciwieństwa skłonił człowieka do } \\
\text { działania wbrew przykazaniu Bożemu. Dopiero kara Boża ujawniła } \\
\text { na czym polega zło, które nie pochodzi jednak z substancji, ale jest } \\
\text { wynikiem przekroczenia przykazania. Śmierć człowieka jako rodzaj kary } \\
\text { jest wynikiem sprawiedliwości, gdyż Bóg wcześniej udzielił przestrogi, } \\
\text { a akt nieposłuszeństwa był złem. Podobnie kara wymierzona diabłu } \\
\text { jest sprawiedliwa, gdyż stworzony jako anioł rozumny dokonał aktu } \\
\text { nieposłuszeństwa, powodowany zazdrością o wyjątkowy status człowieka. }\end{array}$ \\
\hline 19,1 & D1 & $\begin{array}{l}\text { Pytanie: czy diabeł był zły od początku czy też stał się takim już po } \\
\text { stworzeniu? }\end{array}$ \\
\hline $19,2-6$ & $\mathrm{M}$ & $\begin{array}{l}\text { Odpowiedź: Diabeł został stworzony jako dobry. Zazdrość wobec człowieka } \\
\text { doprowadziła go do złego wyboru i przewrotności. Diabeł nie jest } \\
\text { niestworzony, a zło nie jest substancją }{ }^{3} \text {. }\end{array}$ \\
\hline 19,7 & D1 & $\begin{array}{l}\text { Pytanie: jeśli diabeł był stworzony jako dobry, to czy Bóg nie wiedział, że } \\
\text { stanie się nieposłuszny i zły? } \\
\text { Argumentacja: Jeśli Bóg nie wiedział, że diabeł okaże nieposłuszeństwo, to } \\
\text { znaczy, że Bóg nie jest wszechwiedzący. }\end{array}$ \\
\hline $19,8-10$ & M & $\begin{array}{l}\text { Teza M5: Bóg jest wszechwiedzący. } \\
\text { Argumentacja: Bóg stwarza, ponieważ chce dzielić się swą dobrocią. } \\
\text { Stworzył (anioła), wiedząc, że ten odwróci się od Niego i stanie się } \\
\text { diabłem, a potem, że doprowadzi człowieka do nieposłuszeństwa. Bóg } \\
\text { jednak jest większy od zła. Stwarza, by objawić swą dobroć, która wobec } \\
\text { nieposłusznego człowieka wyrazi się w odpuszczeniu grzechów. W ten } \\
\text { sposób zło, paradoksalnie, ukazuje naturę dobra, a bez wolności wyboru } \\
\text { pomiędzy dobrem a złem człowiek byłby z konieczności poddany prawom } \\
\text { Bożym i wszystkich czekałby ten sam los. }\end{array}$ \\
\hline
\end{tabular}




\begin{tabular}{|c|c|c|}
\hline 20,1 & D1 & $\begin{array}{l}\text { Pytanie: jeżeli Bóg chce okazać dobroć przez przebaczenie, to dlaczego } \\
\text { nie ukarał diabła zaraz po jego rebelii, ale pozwolił mu działać i uśmiercać } \\
\text { ludzi? } \\
\text { Argumentacja: gdyby Bóg od razu unicestwił diabła, ludzie nie musieliby } \\
\text { umierać. }\end{array}$ \\
\hline $20,2-8$ & M & $\begin{array}{l}\text { Odpowiedź: Unicestwienie natury stworzonej przez Boga nie byłoby aktem } \\
\text { wielkości. Bóg pozostawił diabła, aby ludzie poznali dobro i w osobistej } \\
\text { walce pokonali tego, przez którego wcześniej zostali zwyciężeni. Ta walka } \\
\text { i świadomość własnej niedoskonałości chronią człowieka przed pychą, } \\
\text { a Bóg, który nie chce jego śmierci, uzdalnia go do zwycięstwa. }\end{array}$ \\
\hline 21,1 & D1 & $\begin{array}{l}\text { Powrót do Problemu 1: jeżeli materia nie istniała wiecznie, to dlaczego Bóg } \\
\text { ją stworzył? }\end{array}$ \\
\hline $21,2-10$ & M & 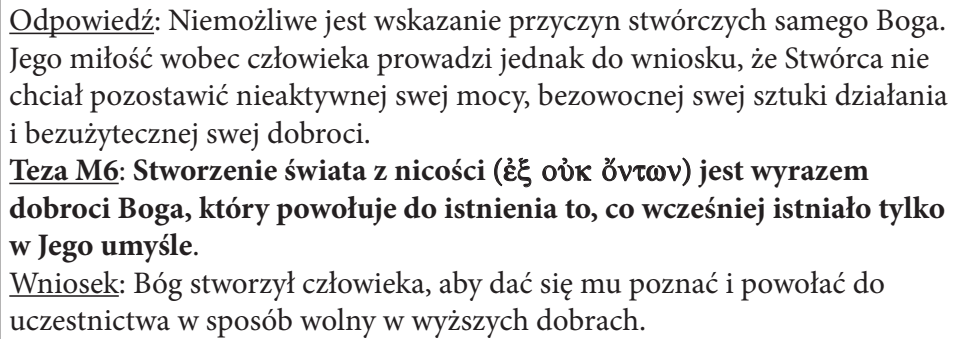 \\
\hline 21,1 & M & $\begin{array}{l}\text { Epilog: } \\
\text { „Nie istniało nic współwiecznego z Bogiem i On sam z niczego stworzył } \\
\text { wszystko. Pierwotnie nie naśladował też sposobu działania jakie teraz } \\
\text { jest właściwe człowiekowi, gdyż jest większy od ludzkiej natury. Nie } \\
\text { stworzył tylko form ani nie zmieszał własnej istoty z innymi substancjami } \\
\text { (materialnymi), gdyż On sam jest Stwórcą (wszystkich) substancji”4. }\end{array}$ \\
\hline
\end{tabular}

1 W dalszych komentarzach stosowana będzie łacińska nazwa creatio ex nihilo.

2 Podobne wyjaśnienie zawarł Metody w De resurrectione I, 37; II, 2. Motyw zazdrości diabła o człowieka (obok tego związanego z pychą) jako przyczyna jego nieposłuszeństwa i degradacji, występuje często w literaturze wczesnochrześcijańskiej. Metody zaczerpnął go prawdopodobnie od Ireneusza z Lyonu, Adversus haereses IV, 40, 3; V, 24, 4.

3 Próbę wyjaśnienia pochodzenia zła, w tym przyczyn upadku diabła i jego roli w grzechu pierwszych ludzi, podjął Metody również w De resurrectione I, 36-37.

4 De autexusio 21, 1, R. Franchi (ed.), s. 338, tłum. własne. 


\section{Ideowe stanowiska rozmówców}

De autexusio powstało $\mathrm{w}$ określonym kontekście kulturowo-ideowym, w którym platonizm odgrywał ważną rolę. Metody pozostawał pod jego wpływem, choć często zajmował wobec niego stanowisko krytyczne, zwłaszcza w kwestii pryncypiów metafizycznych oraz ich kosmologicznych i antropologicznych aplikacji ${ }^{28}$. W drugiej połowie III w. w nurtach myślowych, pozostających pod wpływem średniego platonizmu, dużą popularnością cieszyła się dychotomiczna koncepcja metafizyczna. Obok Boga i świata jego idei, odwiecznie istnieć miała nieuformowana, pierwotna materia, służąca jako budulec do tworzenia widzialnego świata ${ }^{29}$. W gnostycyzmie ta materia uznawana była za antyboską substancję, powstałą z niskich namiętności ${ }^{30}$. Tego typu koncepcje dualistyczne, obok określonej wizji materii i jej genezy, wyjaśniały w jakimś sensie pochodzenie zła, przy równoczesnym zachowaniu pryncypium dobroci Boga, który miałby stworzyć świat $\mathrm{z}$ materiału naznaczonego wewnętrzną niedoskonałością.

W De autexusio poglądy platońskie na temat materii i pochodzenia zła są wyrażane przez dwie bezimienne i fikcyjne postaci. Próby określenia ich reprezentatywności dla określonych nurtów filozoficzno-religijnych nie doczekały się jednoznacznego i przekonującego rozwiązania. Wydaje się jednak, że przy wszystkich podobieństwach nie należy ich utożsamiać $\mathrm{z}$ walentynianami ${ }^{31}$ ani $\mathrm{z}$ jakimś innym określonym ruchem heretyckim ${ }^{32}$.

28 Szerzej por. A. Jahn, S. Methodii opera; M. Margheritis, Influenza di Platone; J. Pépin, Platonisme et Stoïcisme; A. Bril, Plato and the Sympotic Form.

29 Koncepcja odwiecznie istniejącej materii jako czystej potencjalności, znajduje się już w niektórych dziełach Platona, por. Timeaeus 48e-49a; 51a-b. Ta pierwotna materia, pozostająca w stanie nieustannego pobudzenia, jest znakiem i cechą jej niedoskonałości, a w konsekwencji przyczyną zła, por. A. W. Nightingale, Plato on the Origins of Evil: The Statesman Myth Reconsidered.

30 Szerzej: E. Mc Mullin, The Concept of Matter.

31 Identyfikacja Dualisty $1 \mathrm{z}$ gnostykiem Walentynem (por. T. Barnes, Methodius, s. 53), albo jakimś jego uczniem, oparta na słabych podstawach, została w ostatnich dziesięcioleciach przezwyciężona. To prawda, że w manuskrypcie Laurentianus, wyrażającym w jakimś sensie recepcję De autexusio w kolejnych pokoleniach chrześcijan, Dualista 1 został określony skrótem ov̉ $(\alpha)$ (walentynianin), jednakże precyzyjna analiza jego poglądów na temat materii, której nigdzie nie uznał za złą samą w sobie, odróżnia go wyraźnie od tego nurtu gnostyckiego. L.G. Patterson, który początkowo przyjmował taką identyfikację ("De libero arbitrio" and Methodius' Attack on Origen), ostatecznie zerwał z tą hipotezą na rzecz uznania Dualisty 1 za reprezentanta szerokiego nurtu dualizmu kosmologicznego, por. Methodius of Olympus, s. 60-63.

32 K. Bracht, Vollkommenheit and Vollendung, s. 52. 


\subsection{Poglądy Dualisty 1}

Kluczowym przekonaniem Dualisty 1 jest to, że Bóg jest dobry i nie może być źródłem zła. Suponuje on, że Stworzyciel (demiurg) ukształtował świat

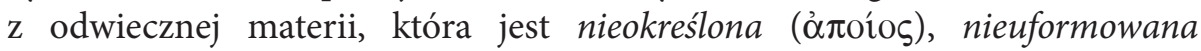

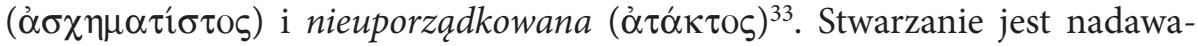
niem formy i porządkowaniem, to znaczy przekształcaniem pierwotnego chaosu w harmonijny kosmos. Pozostałe resztki nieuporządkowanej materii są elementami zamętu w świecie i jako takie są przyczyną zła w człowieku. Sama pierwotna materia nie została jednak nigdzie określona przez Dualiste 1 jako zła z powodu swej substancji. Poza podstawowym założeniem dualistycznym, wprowadzonym dla wyjaśnienia przyczyny zła, jego wypowiedzi nie wykazują żadnych zbieżności leksykalnych i semantycznych z poglądami walentynian ${ }^{34}$. Przypominają za to $\mathrm{w}$ dużej mierze teorie i słownictwo średniego platonizmu, reprezentowanego przez takie postaci jak Alkinos, Plutarch, Numeniusz, Attyk, Chalcydiusz. Platonicy tego nurtu uznawali pierwotną nieuformowaną materię za współistniejącą obok boga (demiurga), który w akcie stwórczym świata porządkował ją. Dualista 1, oprócz określonych założeń filozoficznych, nawiązuje do pewnych opisów biblijnych ${ }^{35}$. Precyzyjna analiza jego wypowiedzi prowadzi do wniosku, że mamy do czynienia z reprezentantem jakiejś odmiany chrześcijańskich poglądów, najprawdopodobniej średniego platonizmu w łonie Kościoła ${ }^{36}$. Nie wyklucza to jednak jakiś związków z gnostycyzmem, biorąc zwłaszcza pod uwagę złożoność kontekstu kulturowego i wzajemne oddziaływanie nurtów filozoficzno-religijnych.

\subsection{Poglądy Dualisty 2}

Rola tej postaci jest w De autexusio stosunkowo ograniczona. W porównaniu do swego przedmówcy, Dualista 2 jest przekonany, że istniejąca odwiecznie pierwotna materia od początku ma właściwości zarówno dobre, jak i złe. Taka koncepcja w sposób bardzo prosty starała się wyjaśnić istnienie zła na świecie, a jednocześnie nie obciążała Boga odpowiedzialnością za nie. Dualista 2 utrzymuje, że zło jest jedną z odwiecznych właściwości materii. Bóg podczas

33 De autexusio 3,9.

34 A. Vaillant, Introduction, s. 640; R. Franchi, Introduzione, s. 66.

35 W passusach wypowiadanych przez Dualistę 1, znajdują się odniesienia do arki Noego (De autexusio 2, 2) czy opisu stworzenia świata z Rdz 1 (De autexusio 2, 9).

36 K. Bracht, Vollkommenheit and Vollendung, s. 57-58; R. Franchi, Introduzione, $69-70$. 
stworzenia mógł jedynie pewne obojętne właściwości udoskonalić. Nie mógł jednak zmienić tych złych, złączonych odwiecznie z materią ${ }^{37}$.

Próba uznania Dualisty 2 za reprezentanta jakiegoś szczególnego nurtu filozoficznego czy religijnego nastręcza wiele trudności. Niektórzy współcześni badacze ${ }^{38}$ próbują zinterpretować tę postać w świetle innego dzieła Metodego, zatytułowanego „[Xenon lub] o stworzeniu”39. Jednym z bohaterów tego ostatniego dialogu, zachowanego jedynie fragmentarycznie, jest niejaki Centaur, zwolennik pewnych idei post-orygeniańskich, w tym wieczności stworzenia. Nie podejmując rozważań na temat tej zawiłej problematyki ${ }^{40}$, ograniczamy się tu do podkreślenia istotnych podobieństw konceptualnych i leksykalnych dotyczących materii, określonej zarówno przez Centaura, jak i Dualistę 2 jako

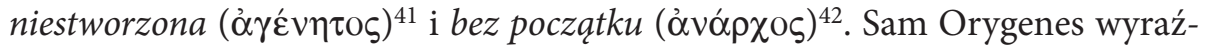
nie twierdził, że Bóg jest stwórcą materii i czterech podstawowych substancji, z odpowiedniego połączenia których utworzył cały świat. Te cztery substancje określone przez jakości są jednak zmienne, tak że wszystko może się przekształcić we wszystko. Sama zaś materia może być oddzielona od jakości jedynie w procesie abstrakcji umysłowej, a w rzeczywistości bez nich nigdzie nie występuje ${ }^{43}$. Dualista 2 nie jest zatem personifikacją Orygenesa. Niewykluczone jednak, że reprezentuje poglądy pewnego nurtu orygeniańskiego, powstałego w wyniku długoletniej polemiki ${ }^{44}$.

\subsection{Poglądy Ortodoksa (Metodego)}

Obrońca doktryny chrześcijańskiej jest orędownikiem idei stworzenia ex nihilo. Jego wypowiedzi mają dwojaką celowość: negatywną i pozytywną. Pierwsza ma za zadanie wykazać niezasadność teorii dualistycznych, druga - udowodnić przy pomocy argumentów prawdziwość własnego stanowiska.

Polemizując z Dualistą 1, Metody stara się wyprowadzić ostateczne konsekwencje z jego wypowiedzi i w ten sposób doprowadzić do obalenia jego pier-

\footnotetext{
37 De autexusio 9,2; 10,3-8.

38 L.G. Patterson, "De libero arbitrio", s. 162-163; K. Bracht, Vollkommenheit and Vollendung, s. 59-68; R. Franchi, Introduzione, 76-77.

39 Methodius, De creatis, GCS 27, s. 491-500.

40 Szerzej: V. Cvetkovic, From Adamantius to Centaur.

41 De creatis 5-7,2; De autexusio 10,6.

42 De creatis 2,2; De autexusio 9,3.

43 Origenes, De principiis II, 1, 4.

44 Na temat kontrowersji orygeniańskiej, E.A. Clark, The Origenist Controversy; E. Prinzivalli, Magister Ecclesiae.
} 
wotnych założeń. Analizując hipotezę o współistnieniu Boga i materii, przedstawia on trzy możliwe sposoby wspólnego bytowania: a) Bóg jest zjednoczony $\mathrm{z}$ materią; b) Bóg jest oddzielony od materii; c) Bóg przebywa w materii, jak w jakimś miejscu. Pierwsza możliwość prowadzi do wniosku, że nie istnieją dwa odwieczne pryncypia, lecz dwie części tego samego niestworzonego bytu; druga, że pomiędzy Bogiem a materią musi istnieć jakieś trzecie odwieczne pryncypium (tertium quid), które ich rozdziela; trzecia, że Bóg jest ogarniony i w jakimś sensie zależny od materialnej substancji.

Argumentacja Metodego odpowiada klasycznej polemice z dualizmem platońskim przeprowadzonej w oparciu o główne założenie stoicyzmu o istnieniu jednego niestworzonego pryncypium ${ }^{45}$. Była ona rozpowszechniona $\mathrm{w}$ środowiskach chrześcijańskich już od czasów Justyna. Za najcelniejsze i najbardziej logiczne rozwiązanie uznał Metody koncepcję creatio ex nihilo, która w jego czasach zdobywała w Kościele status obowiązującej.

Na podstawie tej koncepcji Metody przeprowadził też krytykę poglądów Dualisty 2 o odwiecznym istnieniu materii z dobrymi i złymi właściwościami. Według takiej koncepcji Bóg jawi się bowiem albo jako bezsilny wobec zła („chce, a nie może”), albo złośliwy („może, ale nie chce”). Ponadto, jeżeli nie powołałby do istnienia ani samej materii, ani jej właściwości, to zakwestionowana zostaje jego rola Stwórcy ${ }^{46}$.

Refleksja nad kluczowym dylematem, tj. pochodzeniem zła, jest przeprowadzona w De autexusio w sposób szczegółowy i precyzyjny. Metody odrzuca zarówno koncepcję zła jako substancji (materialnej), jak i zła rozumianego jako jakość substancji ${ }^{47}$. W tym drugim przypadku bowiem Bóg jako twórca jakości materialnych byłby odpowiedzialny za powstanie zła. Poszukiwanie rozwiązania doprowadziło Metodego do przeniesienia argumentacji z przestrzeni metafizyczno-kosmologicznej na antropologiczną. Porównał on sposób istnienia zła do bytowania gatunku, mającego swe realne istnienie w poszczególnych jednostkach. Tak jak one są stwarzane pojedynczo, tak również poszczególne złe czyny mają swego twórcę. Zło, podobnie jak gatunek, nie istnieje jako realna substancja ${ }^{48}$. Tak mocne podkreślenie, że zło nie jest odwieczne, lecz że powstało w czasie, stanowi wyraźną polemikę z tymi koncepcjami kosmologicznymi, które wskazywały materię jako jego przyczynę ${ }^{49}$.

J. Pépin, Platonisme et Stoïcisme, s. 137-141.

De autexusio 10,$1 ; 11,3-8$.

47 Ibidem 6,6-8,15.

48 Ibidem 13.

49 K. Bracht, Vollkommenheit and Vollendung, s. 70-77.
} 
Zdaniem Metodego zło objawia się w czynach i dlatego potrzebuje podmiotu działającego. Przyczyną zła jest niewłaściwe użycie wolnej woli przez człowieka i inne byty nią obdarzone $e^{50}$, a dokładnie jest nią nieposłuszeństwo wobec Boga ${ }^{51}$. Taka koncepcja zakłada określoną wizję człowieka, zdolnego rozpoznać, jaka jest wola Boża i gotowego wybrać, zdecydować i wykonać to, co słuszne. Metody, świadomy słabości woli człowieka ${ }^{52}$, ostatecznie jednak poszerza horyzont rozważań o aspekt teologiczny: miłosierdzie Boga, który przebacza nieprawości i nawet ze zła potrafi wyprowadzić dobro, tak aby człowiek nauczył się zwyciężać zło, przez które wcześniej został zwyciężony ${ }^{53}$.

Próba wyjaśnienia przyczyn zła jest głównym problemem De autexusio. Wszyscy rozmówcy są zgodni, że Bóg jest dobry. Przypisywanie mu nieprawości czy złośliwości uważają za absurd. Niemniej, doświadczenie realnego zła w świecie, a zwłaszcza w działaniu człowieka, rodzi problem źródeł nieprawości. Jeśli Bóg jest to dobry, to skąd zło (si Deus est, unde malum)? W dialogu metodiańskim poszukiwania przyczyn przenoszą się z porządku kosmicznego (materii jako substancji) w sferę antropologiczną, a dokładniej w przestrzeń bytów posiadających wolną wolę (a zatem ludzkich i anielskich). Autor utrzymuje, że zło nie jest substancją ani nawet jej jakością, a materia nie jest jego źródłem. W swej najgłębszej istocie zło jest aktem nieposłuszeństwa wobec Boga istoty wolnej i rozumnej.

\section{Bibliografia}

\section{Edycje De autexusio}

Metodio: Il libero arbitrio, R. Franchi (red. i tłum. wł.), Milano 2015. Méthode d'Olympe: Le „De autexusio", Patrologia Orientalis 22/5, A. Vaillant (red. i tłum. fr.), Paris 1930, s. 725-833.

\footnotetext{
50 De autexusio 16-17.

51 Ibidem 17,2.

52 Św. Paweł pisał o prawie grzechu, mieszkającym w człowieku. Ta dramatyczna kondycja wyraża się w tym, że kiedy chce się czynić dobro, narzuca się zło. Ostateczny ratunek Apostoł znajduje w Chrystusie Zbawicielu (Rz 7, 18-25).

53 De autexusio 19,$8 ; 20,4$.
} 
Methodius: De autexusio, GCS 27, G.N. Bonwetsch (red. i tłum. niem.), Leipzig 1917, s. 143-206.

\section{Dzieła starożytne}

Adamantius (Anonymus), De recta in Deum fide, Bakhuyzen van de Sande (red.), GCS 4, Leipzig 1901.

Eusebius, Praeparatio evangelica, VII, SCh 215, G. Schroeder, É. De Places (red.), Paris 1975.

Hieronymus, Apologia adversus libros Rufini, SCh 303, P. Lardet (red.), Paris 1983.

Hieronymus, De viris illustribus, Biblioteca Patristica 12, A. Ceresa-Gastaldo, Firenze 1988.

Methodius, [Xenon vel] De creatis, GCS 27, G.N. Bonwetsch (red.), Leipzig 1917, s. $491-500$.

Methodius, [Aglaophon vel] De resurrectione, GCS 27, G.N. Bonwetsch (red.), Leipzig 1917, s. 217-242.

Methodius, Symposium, w: Méthode d'Olympe: Le Banquet, H.A. Musurillo, V.H. Debidour (red.), SCh 95, Paris 1963.

Origenes, De principiis, II, SCh 252, H. Crouzel, M. Simonetti (red.), Paris 1978.

Origenes, Philocalia, XXIV, SCh 226, É. Junod, Paris 1976.

Plato, Timaeus, R.G. Bury (red.), Cambridge 1981.

\section{Opracowania}

Barnes T.D., Methodius, Maximus and Valentinus, JThS 30 (1979), s. 47-55.

Bracht K., Vollkommenheit und Vollendung. Zur Anthropologie des Methodius von Olympus, Studien und Texte zu Antike und Christentum 2, Tübingen 1999.

Bril A., Plato and the Sympotic Form in the "Symposium” of St. Methodius of Olympus, Zeitschrift für Antikes Christentum 9 (2006), s. 279-302.

Buchheit Z., Studien zu Methodios of Olympos, Berlin 1958.

Clark E.A., The Origenist Controversy: the Cultural Construction of an Early Christian Debate, Princeton 1992.

Cvetkovic V., From Adamantius to Centaur: St. Methodius of Olympus' Critique to Origen, w: Origeniana Decima: Origen as Writer. Papers of the 10th International Origen Congress, Krakow: 31.08 - 04.09.2009, Bibliotheca Ephemeridum Theologicarum Lovaniensium, t. 244, S. Kaczmarek - H. Pietras (red.), Leuven-Paris-Walpole 2011.

Franchi R., Appendice IX, w: Metodio d'Olimpo, Il libero arbitrio, Milano 2015, s. 407-412.

Franchi R., Introduzione, w: Metodio d'Olimpo, Il libero arbitrio, Milano 2015, s. 9-149. Franchi R., Eusebio di Cesarea, Hist. Eccl. 5.27 e Praep. Ev. 7.21.5. Indagine sul caso di Massimo autore fantasma, Sacris Erudiri 48 (2009), s. 5-34.

Jahn A., S. Methodii opera et S. Methodius platonizans, Halle 1865. 
Margheritis M., Influenza di Platone sul pensiero e sull'arte di S. Metodio d'Olimpo, w: Studi dedicati alla memoria di Paolo Ubaldi, A. Gemelli (red.), Milano 1937, s. 401-412.

Mc Mullin E., The Concept of Matter in Greek and Medieval Philosophy, Notre Dame (IN) 1965.

Mejzner M., Zapomniany nauczyciel wiary. Studium historyczno-teologiczne nad postacia Metodego z Olimpu, Teologia patrystyczna 9 (2012), s. 23-40.

Mejzner M., Wędrówki ku sacrum, Ząbki 2017.

Moreschini C., Storia della filosofia patristica, vol. I, Brescia 2004.

Nightingale A.W., Plato on the Origins of Evil: The Statesman Myth Reconsidered, Ancient Philosophy 16 (1996), s. 65-91.

Patterson L. G., "De libero arbitrio" and Methodius' Attack on Origen, Studia Patristica 14, E.A. Livingstone (red.), Berlin 1976, s. 160-166.

Patterson L. G., Methodius of Olympus. Divine Sovreignty, Human Freedom and Life in Christ, Washington 1997.

Pépin J, Platonisme et Stö̈cisme dans le "De autexusio" de Méthode d'Olympe, w: "Forma Futuri”. Studi in onore del Cardinale Michele Pellegrino, M. Pellegrino (red.), Torino 1975, s. 126-144.

Prinzivalli E., Magister Ecclesiae. Il dibattito su Origene fra III e IV secolo, SEA 82, Roma 2002.

Ramelli I., Maximus on Evil, Matter and God: Arguments for the Identification of the Source of Eusebius, PE VII,22 with Maximus of Tyre, Adamantius 16 (2010), s. 230-255.

Robinson J.A., The Philocalia of Origen, Cambridge 1893.

Routh M. J., Reliquiae Sacrae, vol. II, Oxford 1846.

Vaillant A., Introduction, PO 22/5, Paris 1930, s. 629-723.

Voss B.R., Der Dialog in der frühchristlicher Literatur, München 1970.

Zahn T., Die Dialoge des „Adamantius” mit den Gnostikern, ZKG 9 (1888), s. 193-239.

Zorzi S.B., Introduzione: Metodio di Olimpo, w: Metodio di Olimpo, La risurrezione, M. Mejzner - S.B. Zorzi (red.), Collana di Testi Patristici 216, Roma 2010, s. 5-33.

Zorzi S.B., Metodio d'Olimpo, un autore minore?, REAP 52 (2006), s. 31-56. 